\title{
DESIGN AND MANUFACTURE A PROTOTYPE OF YEMENI COFFEE HULLER MACHINE
}

\section{Abdel El-Elah Omer Saif*}

\section{ABSTRACT}

The design, construction and development of a huller is described in this paper. Some engineering properties were studied as important parameters affecting the design of the huller machine, and the results showed that, the highest frequency length, width and thickness of the coffee grains were 1.0, 0.7 and $0.7 \mathrm{~cm}$. The medium size (from 7-10 mm) was denser than both small and large sizes of coffee as the porosity of that size was lower than those of both small and large sizes. The angle of repose increased with the decrease of coffee size. It ranged from 8.75 to 14.30 degrees on the glass surface. The huller consists basically of a drum, hopper, fan, motor, frame, belts and pulleys. It was tested at different speeds and feeding rated. The results indicated that the huller productivity increased with increasing the drum rotation speed and feeding rate. The productivity ranged from $240-360 \mathrm{~kg} / \mathrm{h}$. It could be used for hulling the coffee beans at higher rotation speeds with high efficiency.

Keyword: huller, coffee beans, peeling, productivity.

\section{INTRODUCTION}

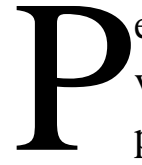

eeling is an important step in the processing of most fruits and vegetables. Chemical peeling (mostly lye peeling), mechanical peeling (mainly abrasion peeling), steam peeling and freeze peeling are conventional methods for peeling in the processing of fruits and vegetables (Schlimme, Corey, \& Frey, 1984; Ben-Shalom, Levi, \& Pinto, 1986; Floras, Wetzstein, \& Chinnan, 1987; Floras \& Chinnan, 1988a, b, 1990; Bolin and Huxoll, 1991; Garrote, Coutaz, Luna, Silva, \& Bertone, 1993; Setty, Vijayalakshmi, \& Devi, 1993; Garrote, Coutaz, Silva, \& Bertone, 1994; Bayindirli, Bayindirli, Sahin, Sumnu, \& Gider, 1996; Garrote, Silva, Bertone, \& Avalle, 1997). Despite providing different advantages, most of the conventional methods of peeling often cause high peeling losses and damage the flesh, affecting the quality of the fruit. Enzymatic peeling was suggested as a more recent alternative.

\footnotetext{
*Prof. Dr. of Agric. Eng. Dept., Faculty of Agriculture Sana'a Univ., Yemen
} 
Pectin, cellulose and hemi-cellulose are the polysaccharides responsible for the adherence of the peel to the fruit. Therefore, treating the fruit with the corresponding lycohydrolases provides the peeling of the fruit (Pretel, Lozano, Riquelme, \& Romojaro, 1997). Since harsh treatments are not involved, the amount of broken segments and juice losses is much less than the classical methods and the peeled fruit has a better texture and appearance (Janser, 1996).

Besides the fact that there is a limited amount of work in literature regarding enzymatic peeling, almost all of these researches are about enzymatic peeling of citrus fruits (Ben-Shalom et al., 1986; Rouhana \& Mannheim, 1994; Soffer \& Mannheim, 1996; Pretel et al., 1997). As a result of these studies, the method was proven to be applicable and optimum peeling condition s of citrus fruits were determined. Following the researches for the enzymatic peeling of citrus fruits, trials were conducted for the enzymatic peeling of stone fruits and the feasibility of the process was shown (Janser, 1996). Better understanding of enzymatic peeling of stone fruits would probably facilitate and promote its industrial application. The objectives of this study were to investigate timetemperature-pH-enzyme concentration relations for enzymatic peeling of apricots, nectarines and peaches by using four different enzyme preparations (Peelzym I, II, III and IV) and to determine the optimum peeling conditions using response surface methodology.

Coffee is an extremely important crop in Yemen. Coffee growing started since $14^{\text {th }}$ century, the Yemenis highlands can be considered as secondary center of origin of Cafea Arabia L (Sylvian, 1956 and Eskes and Mukred, 1989). In Yemen, coffee grows on valleys and at terraces. Coffee quality is a function of the inherent characteristics of the cultivars grown which are then modified by the influences of the environment. Bean size is the reflection on both these factors and the field husbandry practices. While the quality is already determined at harvesting and may not be subsequently improved, poor harvesting and farm processing can ruin this pre-established quality. Harvesting and farm processing have no effect on bean size. 
The coffee fruit comprises the pulp which houses the parchment, surrounded by a layer of mucilage. The fruit of the Arabica coffee in which the pulp is removed from the ripe fruit by a pulping process, the mucilaging and washing processes and the parchments are dried on the estate where they are grown. The dried parchment and cherry are further processed by hulling, sorting and grading.

Many researches have been carried out on the physical and engineering properties of the agricultural products (Mohsenin, 1970; Abd Alla et al., 1995; Korayem and Soliman, 1983; Muir and Sinha, 1988; Kukelko et al., 1988; Irvine et al, 1992; and El-Raie et al., 1996). The information on size, density, and crushing strength are required for the development of the grading system for barriers and for the pulpers (Gosh, 1969). The physical properties such as size, friction angle, angle of repose, crushing strength and bulk density are important in the design of the handling system, grading and hulling (Chandrasekar and Viswanathan, 1999). Abd Alla et al. (1995) reported that the shape index and coefficient of contact surface had a high significant effect on the rupture force and broken percentage in milling process of rice grains Surface areas of fruits are important in investigations related to spray coverage, respiration rate, light reflectance, color evaluation and heat transfer studies in heating and cooling processes (Mohsenin, 1970).

The characteristic flavor and aroma of coffee result from a combination of hundreds of chemical compounds produced by the reactions that occur during roasting. This process can be divided into three consecutive stages: (i) drying, (ii) roasting or pyrolysis and (iii) cooling. The first stage is characterized by a slow release of water and volatile substances, during the first half of processing. Bean color changes from green to yellow. Pyrolysis reactions take place during the second stage, resulting in considerable changes in both physical and chemical properties of the beans. Large quantities of $\mathrm{CO}$, water and volatile substances are released and the beans turn brown, due to sugar caramelization coupled to Maillard reactions. At this point cooling is required in order to avoid burning the coffee (Sivetz \& Desrosier, 1979; Rodrigues, Borges, Franca, Oliveira, \& Correa, 2003). 
Roasting is a complex process from a chemistry point of view, since hundreds of chemical reactions take place simultaneously. Some examples include Maillard and Strecker reactions, degradation of proteins, polysaccharides, trigonelline and chlorogenic acids (De Maria, Trugo, Aquino Neto, Moreira, \& Alviano, 1996). Sugars and trigonelline will act as aroma precursors, originating several substances (furans, pyrazines, pirroles, pyridines, etc.) that will affect both the flavor and aroma of the beverage. Thermal degradation of chlorogenic acids will result on phenolic substances that will contribute to bitterness (Clifford, 1985). Even though caffeine does not take part in any reaction, it should also contribute to bitterness, besides its known pharmacological effects (Macrae, 1985). Thus, evaluation of trigonelline, chlorogenic acids and caffeine, in both green and roasted coffee, could be of relevance in establishing coffee quality. Furthermore, a few studies have proposed the use of these substances for determination of the degree of roast (Stennert \& Maier, 1996), as genotype selection criteria (Guerrero \& Suárez, 2001) and for species differentiation (Martín, Pablos, \& González, 1998; Ky et al., 2001). The quality of coffee is commonly evaluated according to criteria such as bean size, color, shape, processing method, crop year, flavor and presence of defects (Banks, McFadden, \& Atkinson, 1999). Among those, flavor (cup quality) and presence of defects (type classification) are the most important criteria employed worldwide in coffee trading.

The high labour demand of coffee production and processing, Coffee peeling is the most labour intensive operation in coffee processing, involving tedious time-consuming manual labour. The main objective of this study was to design and manufacture a prototype of coffee huller machine which assure good quality and saving energy.

\section{EXPERIMENTAL PROCEDURES}

The coffee used in the study was obtained from a local market. The study was carried out on the most common variety namely, Esmaely. The coffee berries were cleaned manually by hand removal of all foreign matter such as stones, dirt and broken seeds. The engineering parameters of this variety were studied. 


\section{Coffee bean huller machine:}

The constructional drawings of the huller is shown in fig. 1. The main parts of the huller are frame, hopper (made of iron sheet with $2 \mathrm{~mm}$ thickness), an abrasive drum (cylindrical in shape made of stainless steel with a diameter of $17.5 \mathrm{~cm}$, fixed on it a blades with a thickness of 1.25 $\mathrm{cm}$ with total diameter of $20 \mathrm{~cm}$ ), drum case, motor, blower, air reflector and sieve (made of iron sheet thickness $0.5 \mathrm{~mm}$ with $10 \mathrm{~mm}$ hole diameter). The drum was fixed on a horizontal shaft supported by two ball bearings fixed over a frame size $80 \times 60 \mathrm{~cm}$. The drum is rotated by means of belts and pulleys connected to $0.75 \mathrm{hp}$ single phase electric motor (1450 rpm and $220 \mathrm{~V})$.

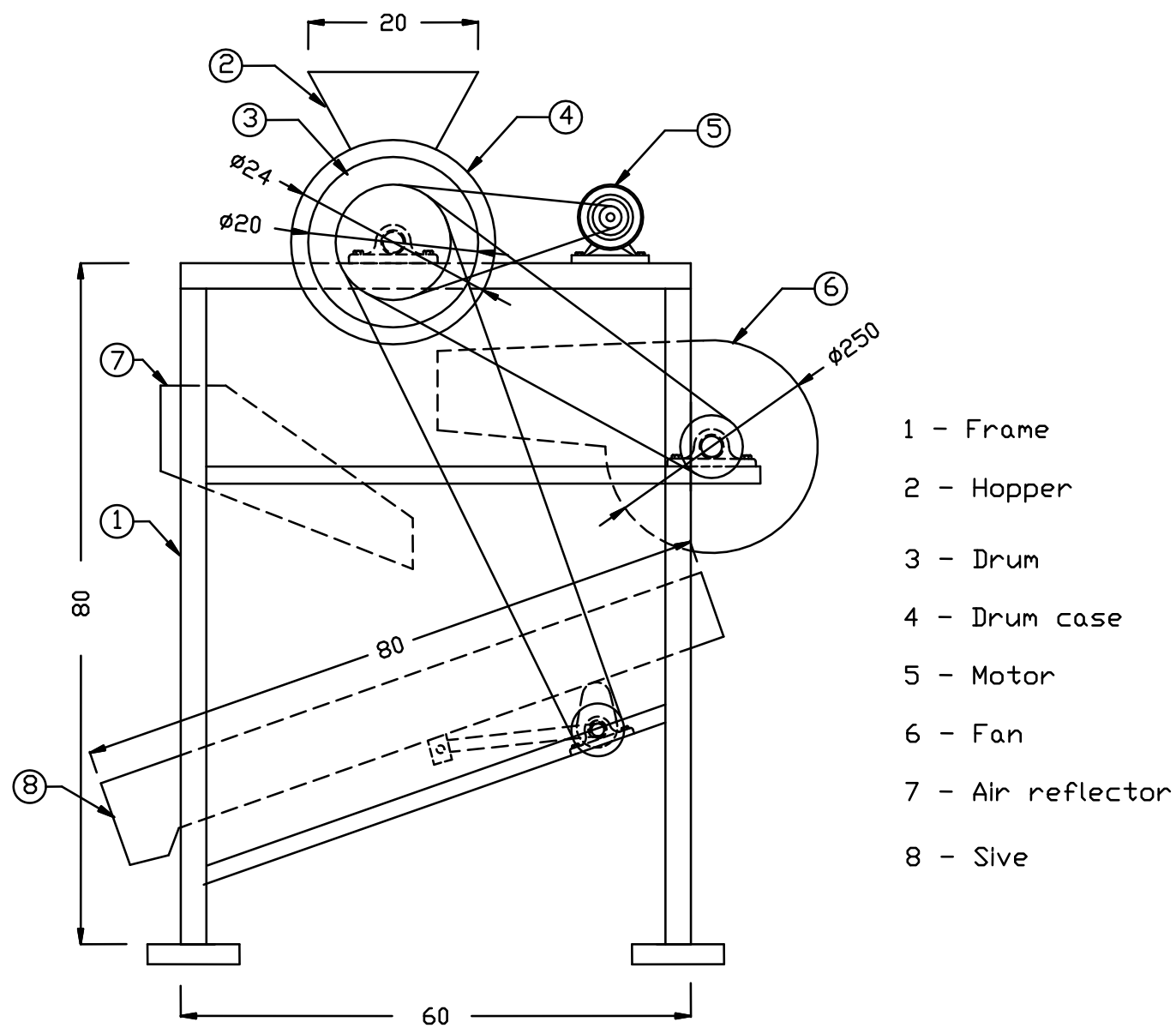

Fig. 1. Coffee bean huller machine. 
The machine was set for the experiment, a sample of 4,5, $6 \mathrm{~kg}$ of coffee grains was weighed and fed into the machine drum, the drum was rotated at speeds of 150, 200 and $250 \mathrm{rpm}$. The speed was varied by changing the pulley of the drum shaft. Each experiment was carried out in triplicate and average values are reported:

\section{Apparatus and Procedure}

\section{Linear Dimensions:}

One hundred berries were randomly selected from the remainder of the 10 $\mathrm{kg}$ sample. The three linear dimensions, namely, length $\mathrm{L}$, width $\mathrm{W}$, and thickness $\mathrm{T}$, of each the 100 berries were measured with a caliper reading to $0.01 \mathrm{~mm}$. The geometric mean diameter, arithmetic diameter, volume, frontal surface and cross-sectional of areas of the grains were calculated using the relationships given by Mohsenin (1970), as follows:

$$
\begin{aligned}
& \text { Sphericity }=100 \frac{(\mathrm{LWT})^{0.333}}{\mathrm{~L}}, \% \\
& \text { Volume }=\frac{\pi}{6} \mathrm{LWT}, \mathrm{mm}^{3} \\
& \text { Geometric diameter }=(\mathrm{LWT})^{0.333}, \mathrm{~mm} \\
& \text { Arithmetic diameter }=\frac{(\mathrm{L}+\mathrm{W}+\mathrm{T})}{3}, \mathrm{~mm} \\
& \text { Frontal surface area }=\frac{\pi}{4} \mathrm{LW}, \mathrm{mm}^{2} \\
& \text { Cross - sectional of area }=\frac{\pi}{4} \frac{(\mathrm{L}+\mathrm{W}+\mathrm{T})^{2}}{3}, \mathrm{~mm}^{2}
\end{aligned}
$$

\section{Shape Index:}

Shape index is used to evaluate the shape of the coffee berries and calculated according to the following equation (Abd Alla, 1993):

$$
\text { Shape Index }=\frac{\mathrm{L}}{\sqrt{\mathrm{W} * \mathrm{~T}}}
$$


The coffee berry is considered an oval if the shape index $>1.5$ on the other hand it is considered spherical if the shape index $\leq 1.5$.

\section{Coefficient of Contact Surface:}

The coefficient of contact surface is very important parameter to evaluate the contact surface between the berry and the other surfaces such as milling machine's surface. This coefficient can be calculated using the following equation (Abd Alla, 1993):

$$
\text { Coefficient of contact surface }=\frac{\mathrm{A}_{\mathrm{f}}-A_{t}}{\mathrm{~A}_{\mathrm{f}}} * 100
$$

Where:

$$
\begin{array}{ll}
\mathrm{A}_{\mathrm{f}} & \text { is the frontal surface area }=\pi / 4 * \mathrm{~L} * \mathrm{~W}, \mathrm{~mm}^{2} \\
\mathrm{~A}_{\mathrm{t}} & \text { is the transverse surface area }=\pi / 4 * \mathrm{~T} * \mathrm{~W}, \mathrm{~mm}^{2}
\end{array}
$$

\section{Determination of Bulk Density of the Coffee Berries:}

The bulk density of the coffee berry was measured by filling a circular container of $1 \mathrm{~L}$ volume and weighing the contents. It was calculated from the mass and volume.

\section{Determination of Angle of Repose}

The repose angle of the three categories of the coffee varieties was determined by allowing the parchment to flow on a plate to form a pile and the angle of repose is measured by fixing a protractor on the side of the plate.

\section{Determination of Coefficient of Static Friction:}

The need for knowledge of the coefficient of friction of the agricultural materials on various surfaces has long been recognized by engineers concerned with rational design of grain bins, silos and other storage structures. Coefficient of static friction is the ratio of the force required to slide grain over a surface divided by the normal force pressing the grain against the surface. Coefficients of friction were determined for grain on four surfaces: galvanized steel, plywood, tin plate and glass. The material surface was fastened to tilting table. A frame made with square wooden bars was placed on the surface. The frame was filled with berries. The table was tilted slowly manually until movement of the whole gain mass and frame was detected by the operator. The coefficient of friction was 
the tangent of the slope angle of the table measured with a protractor (Oje and Ugbor, 1991).

\section{RESULTS AND DISCUSSIONS}

\section{Engineering properties:}

Figure 2 shows the frequency distribution of the coffee berries length, width and thickness, it can be noticed that the highest frequency distribution $(30 \%)$ was at $10 \mathrm{~mm}$ length.

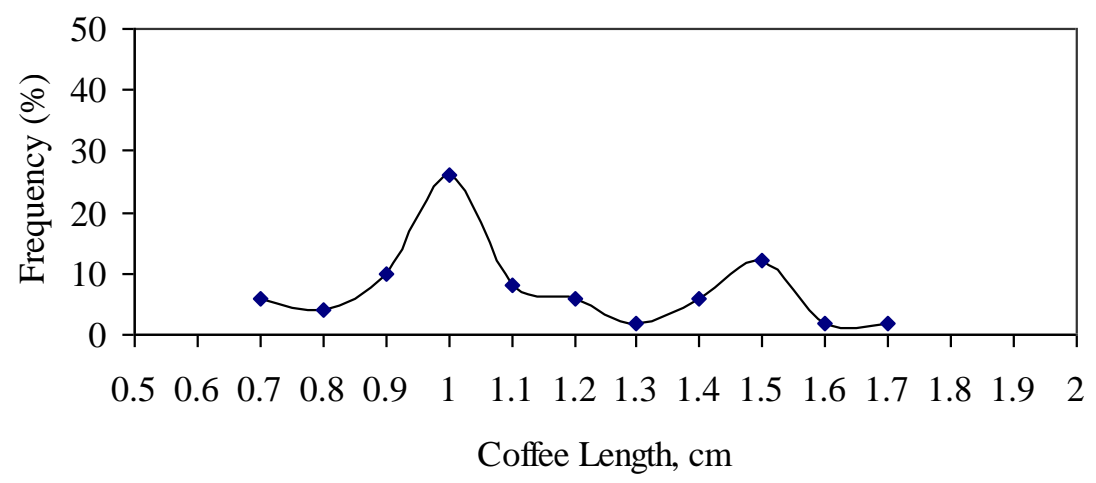

Fig. 1. Frequency distribution of coffee length (L).

\section{Shape Index and Coefficient of Contact Surface:}

The average and standard deviation of the shape index and coefficient of contact surface were estimated for the three sizes of the coffee berries of three different varieties and the data is shown in Table (1). It seems that there were no significant differences between the shape indices and coefficient of contact surface for all the coffee sizes under study.

Table (1): Shape index and coefficient of contact surface.

\begin{tabular}{lcccccc}
\hline Variet & \multicolumn{3}{c}{ Shape index } & \multicolumn{4}{c}{$\begin{array}{c}\text { Coefficient of contact } \\
\text { surface, \% }\end{array}$} \\
\cline { 2 - 7 } & $\begin{array}{c}<7 \\
\mathrm{~mm}\end{array}$ & $\begin{array}{c}\text { From 7-10 } \\
\mathrm{mm}\end{array}$ & $\begin{array}{c}>10 \\
\mathrm{~mm}\end{array}$ & $\begin{array}{c}<7 \\
\mathrm{~mm}\end{array}$ & $\begin{array}{c}\text { From 7- } \\
10 \mathrm{~mm}\end{array}$ & $\begin{array}{c}>10 \\
\mathrm{~mm}\end{array}$ \\
\hline $\begin{array}{c}\text { Esmae } \\
\text { ly }\end{array}$ & 1.15 & 1.43 & 1.32 & 16.7 & 33 & 28.6
\end{tabular}

It indicates also that all the coffee berries are spherical in shape according to Abd Alla (1993). 


\section{Volume, Geometric and Arithmetic Diameters, Frontal and Cross Sectional of Areas and Sphericity Percentage:}

Table (2) shows the mean and standard deviation of volume, geometric and arithmetic diameters, frontal and cross sectional of areas and sphericity percentage for three categories of the coffee berries for three different varieties. The overall mean volume, geometric diameter, arithmetic diameter, frontal surface, cross-sectional of surface area, sphericity \% were $138 \pm 34.7 \mathrm{~mm}^{3}, 6.40 \pm 0.54 \mathrm{~mm}, 6.42 \pm 0.56 \mathrm{~mm}$, $42.10 \pm 6.06 \mathrm{~mm}^{2}, 112 \pm 13.58 \mathrm{~mm}^{2}$, and $85.7 \pm 4.28 \%$, respectively for the small size category for all varieties. The overall mean volume, geometric diameter, arithmetic diameter, frontal surface, cross-sectional of surface area, sphericity $\%$ were $249 \pm 32.42 \mathrm{~mm}^{3}, 7.79 \pm 0.36 \mathrm{~mm}, 7.90 \pm 0.36 \mathrm{~mm}$, $55.5 \pm 5.3 \mathrm{~mm}^{2}, 147.03 \pm 13.58 \mathrm{~mm}^{2}$, and $80.80 \pm 1.87 \%$, respectively for the medium size category for all varieties. The overall mean volume, geometric diameter, arithmetic diameter, frontal surface, cross-sectional of surface area, sphericity $\%$ were $772.33 \pm 109.57 \mathrm{~mm}^{3}, 11.35 \pm 0.57 \mathrm{~mm}$, $11.45 \pm 0.57 \mathrm{~mm}, 119.47 \pm 10.27 \mathrm{~mm}^{2}, 310.73 \pm 29.96 \mathrm{~mm}^{2}$, and $84.27 \pm 1.49 \%$, respectively for the large size category for all varieties.

Table (2): Volume (V), geometric mean diameter (GMD), arithmetic mean diameters (AMD), frontal surface area $\left(A_{f}\right)$, cross-sectional of area $\left(A_{c s}\right)$ and sphericity percentage of coffee berries.

\begin{tabular}{|c|c|c|c|c|c|c|}
\hline $\begin{array}{l}\text { Variet } \\
\mathrm{y}\end{array}$ & $\begin{array}{c}\mathrm{V} \\
\left(\mathrm{mm}^{3}\right)\end{array}$ & $\begin{array}{l}\text { GMD } \\
(\mathrm{mm})\end{array}$ & $\begin{array}{l}\text { AMD } \\
(\mathrm{mm})\end{array}$ & $\begin{array}{c}\mathrm{A}_{\mathrm{f}}, \\
\left(\mathrm{mm}^{2}\right)\end{array}$ & $\begin{array}{c}\mathrm{A}_{\mathrm{cs}} \\
\left(\mathrm{mm}^{2}\right)\end{array}$ & $\begin{array}{c}\text { Sphericity } \\
(\%)\end{array}$ \\
\hline \multicolumn{7}{|c|}{ Category $<7 \mathrm{~mm}$} \\
\hline $\begin{array}{c}\text { Esmae } \\
\text { ly }\end{array}$ & 146 & 6.55 & 6.56 & 36.7 & 101 & 91.0 \\
\hline \multicolumn{7}{|c|}{ Category from $7-10 \mathrm{~mm}$} \\
\hline $\begin{array}{c}\text { Esmae } \\
\text { ly }\end{array}$ & 255 & 7.88 & 8.00 & 57.3 & 150.7 & 78.80 \\
\hline \multicolumn{7}{|c|}{ Category > $10 \mathrm{~mm}$} \\
\hline $\begin{array}{c}\text { Esmae } \\
\text { ly }\end{array}$ & 820 & 11.6 & 11.7 & 123.0 & 324.2 & 82.97 \\
\hline
\end{tabular}




\section{Mass, Bulk Density and Angle of Repose:}

Table (3) shows the mass of 1000 grains, bulk density and angle of repose for three diameters of coffee. It shows that the mass increased with the increase of coffee diameter for all varieties. The bulk density of the coffee berries at the three sizes were 751,801 and $747 \mathrm{~kg} / \mathrm{m}^{3}$ for less than $7 \mathrm{~mm}$, from $7-10 \mathrm{~mm}$ and more than $10 \mathrm{~mm}$, respectively. It seems also that the medium size was denser than both small and large size of coffee as the porosity of that size was lower than those of both small and large sizes. This was maybe due to the smaller size has many berries were not fully ripened which make them lighter than they would be.

Table (3): Mass, bulk density and angle of repose.

\begin{tabular}{lccc}
\hline \hline & $\begin{array}{c}\text { Mass of } 1000 \\
\text { berries }(\mathrm{g})\end{array}$ & $\begin{array}{c}\text { Density } \\
\left(\mathrm{kg} / \mathrm{m}^{3}\right)\end{array}$ & Angle of repose $\left(^{\circ}\right)$ \\
\hline \hline$<7 \mathrm{~mm}$ & \multicolumn{4}{c}{ Esmaely variety } \\
\hline \hline From $7-10 \mathrm{~mm}$ & 265 & 773 & 14.3 \\
\hline \hline$>10 \mathrm{~mm}$ & 810 & 825 & 12.4 \\
\hline \hline Mean & $\mathbf{4 1 5 . 0 0}$ & $\mathbf{7 9 9 . 3 3}$ & $\mathbf{1 2 . 6 3}$ \\
\hline \hline SD & $\mathbf{3 4 5 . 3 6}$ & $\mathbf{2 6 . 0 1}$ & $\mathbf{1 . 5 6}$ \\
\hline
\end{tabular}

The angle of repose increased with the decrease of coffee grain size. It ranged from 8.75 to 14.3 degree on the glass surface.

\subsection{Coefficient of Static Friction:}

Table (4) shows the coefficient of static friction of three sizes of coffee on four different surfaces, plywood, galvanized steel, glass and tin plate for the variety under study. The results showed that the coefficient of static friction decreased with the increase of coffee grain size at all surfaces. The highest value was 0.25 for the small size and the lowest value was 0.2 for the large size. The maximum coefficient of static friction was offered by plywood surface followed by galvanized steel, tin plate, and glass for all categories of the coffee grains, these results agreed with those obtained by Helmy (1995). 
Table (4): Coefficient of static friction.

\begin{tabular}{lcccc}
\hline \hline & \multicolumn{4}{c}{ Friction Coefficient } \\
\cline { 2 - 5 } & $<7 \mathrm{~mm}$ & From 7-10 mm & $>10 \mathrm{~mm}$ & Mean \\
\hline \hline Surface type & \multicolumn{5}{c}{ Esmaely variety } \\
\hline \hline & 0.30 & 0.29 & 0.26 & 0.28 \\
\hline \hline Plywood & 0.27 & 0.24 & 0.22 & 0.24 \\
\hline \hline Galvanized steel & 0.25 & 0.22 & 0.20 & 0.22 \\
\hline \hline Glass & 0.22 & 0.20 & 0.19 & 0.20
\end{tabular}

The mean values were $0.27,0.22,0.20$, and 0.19 for the surfaces in the same pervious order.

\section{Huller performance and its tests:}

The huller was tested at different feeding rates (4, 5, and $6 \mathrm{~kg}$ ), and rotation speeds $(150,200$, and $250 \mathrm{rpm})$. Machine productivity was determined at the previous operation conditions. From Table (5), it could be seen that the productivity increased with increasing the drum rotation speed where, it recorded as high as $360 \mathrm{~kg} / \mathrm{h}$ at $250 \mathrm{rpm}$ rotation speed and $6 \mathrm{~kg}$ feeding quantity, whereas, it recorded $287 \mathrm{~kg} / \mathrm{h}$ at the low rotation speed $(150 \mathrm{rpm})$ at the same feeding rate $(6 \mathrm{~kg})$. regarding, the fractions of both grain and peels, it seems that the percentage of grain ranged from $65-70 \%$, while peels percentage ranged from $25-35 \%$. The results showed that there was no grain breakage during hulling process at $150 \mathrm{rpm}$ rotation speed, while above these speed, the breakage percentage increased with increasing both speed and feeding rate.

Table (5): the productivity, coffee grain, peels and breakage percentage of the tested coffee beans huller machine.

\begin{tabular}{|l|l|l|l|l|l|l|l|l|l|}
\hline $\begin{array}{l}\text { Rotation } \\
\text { speed, RPM }\end{array}$ & \multicolumn{3}{|c|}{150} & \multicolumn{3}{c|}{200} & \multicolumn{3}{c|}{250} \\
\hline Feeding, kg & 4 & 5 & 6 & $4 \mathrm{~kg}$ & 5 & 6 & 4 & 5 & 6 \\
\hline $\begin{array}{l}\text { Productivity, } \\
\text { kg/h }\end{array}$ & 240 & 266 & 287 & 293 & 300 & 320 & 335 & 346 & 360 \\
\hline $\begin{array}{l}\text { Coffee } \\
\text { grain, kg }\end{array}$ & 168 & 172 & 188 & 200 & 210 & 224 & 236 & 241 & 252 \\
\hline Peels, kg & 72 & 94 & 99 & 93 & 90 & 96 & 99 & 105 & 108 \\
\hline Breakage, \% & none & none & none & 0.01 & 0.03 & 0.035 & 0.05 & 0.07 & 0.1 \\
\hline
\end{tabular}


Regression analysis was carried out on the relationship between the productivity (P1, P2, P3) and rotation speed, at different feeding rates (X1, $150 \mathrm{rpm}, \mathrm{X} 2,200 \mathrm{rpm}, \mathrm{X} 3,250$ ), the best fit for this relationship was as follows:

$$
\begin{array}{ll}
\mathrm{P} 1=23.5(\mathrm{X} 1)+217.3 & \left(\mathrm{R}^{2}=0.995\right) \\
\mathrm{P} 2=13.5(\mathrm{X} 2)+277.3 & \left(\mathrm{R}^{2}=0.996\right) \\
\mathrm{P} 3=12.5(\mathrm{X} 3)+322 & \left(\mathrm{R}^{2}=0.928\right)
\end{array}
$$

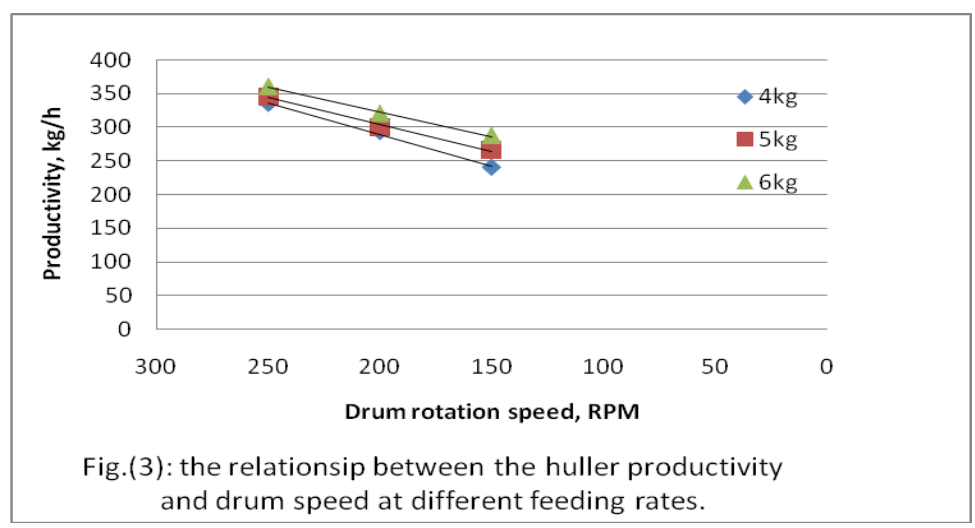

\section{CONCLUSIONS}

- The highest frequency length, width and thickness of the coffee grains were 10.0, 7.0 and $7.0 \mathrm{~mm}$.

- Shape index and coefficient of contact surface revealed that the coffee grains are spherical in shape.

- The medium size (from 7-10 mm) was denser than both small and large size of coffee as the porosity of that size was lower than those of both small and large sizes.

- The angle of repose increased with the decrease of coffee size. It ranged from 8.75 to 14.3 degrees on the glass surface.

- The coefficient of static friction decreased with the increase of coffee size at all surfaces.

- The maximum coefficient of static friction was offered by plywood surface followed by galvanized steel, tin plate, and glass for all categories of the coffee grains. 
- The huller productivity increased with increasing the drum rotation speed and feeding rate.

- The productivity ranged from $240-360 \mathrm{~kg} / \mathrm{h}$.

- It could be used for hulling the coffee beans at higher rotation speeds with high efficiency.

- It is recommended to be a part of a line processing of coffee hulling.

- The author recommend for further studies by establishment a research center concerning all engineering processing of coffee.

\section{REFERENCES}

Abd Alla, H. El-Shabrawe. 1993. Effect of coating process on seeds viability and some physio-mechanical properties of Egyptian cotton. J. Agric. Sci. Mansoura Univ., 18(8):2384-2396.

Abd Alla, H. El-Shabrawe, S. M. Radwan and E. H. El-Hanfy. 1995. Effect of some physical properties of rice grains on milling quality. Misr J. of Agr. Eng., 12(1):143-155.

AOAC (1990) Association of official analytical chemists. $5^{\text {th }}$ Edt., 1990 Pub. by the Association of Official Analytical Chemists, Suite 400 .

Banks, M., C. McFadden and C. Atkinson, (1999) The world encyclopaedia of coffee, Anness Publishing Limited, London (1999).

Chandrasekar, V. and R. Viswanathan. 1999. Physical and thermal properties of coffee. J. Agric. Engng Res. 73, 227-234.

Clifford, M. N. (1985). Chlorogenic acids. In: R. J. Clarke, R. Macrae (Eds.), Coffee, Vol 1: Chemistry (pp. 153-202). London: Elsevier Applied Science.

De Maria, Trugo, Aquino Neto, Moreira, \& Alviano (1996) Composition of green coffee water-soluble fractions and identification of volatiles formed during roasting, Food Chemistry 55 (1996) (3), pp. 203-207. 
Bayindirli, L., Bayindirli, A., Sahin, S., Sumnu, G., \& Gider, S. (1996). Studies on caustic peelingof apples. Journal of Food Science and Technology, 33, 240-242.

Ben-Shalom, N., Levi, A., \& Pinto, R. (1986). Pectolytic enzyme studies for peeling of grapefruit segment membrane. Journal of Food Science, 51, 421-423.

Bolin, H. R., \& Huxoll, C. C. (1991). Control of minimally processed carrot (Daucus carota) surface discoloration caused by abrasion peeling. Journal of Food Science, 56, 416-418.

Box, G. E. P., \& Draper, N. R. (1987). Empirical model-building and response surfaces. New York: Wiley.

Floras, J. D., \& Chinnan, M. S. (1988a). Seven factor response surface optimization of a double-stage lye $(\mathrm{NaOH})$ peeling process for pimiento peppers. Journal of Food Science, 53, 631-638.

Floras, J. D., \& Chinnan, M. S. (1988b). Microstructural changesduringsteam peelingof fruits and vegetables. Journal of Food Science, 53, 849-853.

Floras, J. D., \& Chinnan, M. S. (1990). Diffusion phenomena duringchemical $(\mathrm{NaOH})$ peelingof tomatoes. Journal of Food Science, 55, 552-553.

Floras, J. D., Wetzstein, H. Y., \& Chinnan, M. S. (1987). Chemical $(\mathrm{NaOH})$ peelingas viewed by scanning electron microscopy: Pimiento peppers as a case study. Journal of Food Science, 52,1312-1316.

Garrote, R. L., Coutaz, V. R., Luna, J. A., Silva, E. R., \& Bertone, R. A. (1993). Optimizingprocessing conditions for chemical peelingof potatoes using response surface methodology. Journal of Food Science, 58, 821-826.

Garrote, R. L., Coutaz, V. R., Silva, E. R., \& Bertone, R. A. (1994). Determiningprocess conditions for chemical peelingof asparagus. Lebensmittel-Wissenschaft und Technologie, 27, 19-22. 
Garrote, R. L., Silva, E. R., Bertone, R. A., \& Avalle, A. (1997). Effect of time and number of cycles on yield and peelingquality of steam peeled potatoes and asparagus. Lebensmittel-Wissenschaft und Technologie, 30, 448-451.

Janser, E. (1996). Enzymatic peelingof fruit. Food Processing, 3, 1-4.

Javeri, H., Toledo, R., \& Wicker, L. (1991). Vacuum infusion of pectinmethylesterase and calcium effects on firmness of peaches. Journal of Food Science, 56, 739-742.

Mcardle, R. N., \& Culver, C. A. (1994). Enzyme infusion: A developingtechnolog y. Food Technology, 8, 85-89.

Myers, R. H. (1971). Response surface methodology. Boston: Allyn and Bacon Inc.

Pretel, M. T., Lozano, P., Riquelme, F., \& Romojaro, F. (1997). Pectic enzymes in fresh fruit processing: Optimization of enzymic peeling of oranges. Process Biochemistry, 32, 43-49.

Rouhana, A., \& Mannheim, C. H. (1994). Optimization of enzymatic peelingof grapefruit. Lebensmittel-Wissenschaft und Technologie, 27, 103-107.

Schlimme, D. V., Corey, K. A., \& Frey, B. C. (1984). Evaluation of lye and steam peelingusingfour processing tomato cultivars. Journal of Food Science, 49, 1415-1418.

Setty, G. R., Vijayalakshmi, M. R., \& Devi, A. U. (1993). Methods for peelingfruits and vegetables: A critical evaluation. Journal of Food Science and Technology, 30, 155-162.

Soffer, T., \& Mannheim, C. H. (1996). Optimization of enzymatic peelingof oranges and pomelo. Lebensmittel-Wissenschaft und Technologie, 27, 245-248.

Thompson, D. (1982). Response surface experimentation. Journal of Food Processing and Preservation, 6, 155-188. 
Dutta, S. K., Nema. V. K. and R. K. Bhardwaj. 1972. Physical properties of gram. J. Agric. Eng. Res. 12, 128-137.

El- Raie, A. E.S., Hendawy, N. A. and A.Z. Taib. 1996. Study of physical and engineering properties for some agricultural products. Misr J. of Agr. Eng., 13(1):211-226.

Eskes, A. B. and Mukred, A. W. O. 1989. Coffee survey in PDR Yemen. ASIC, 13, Colloque, Piape, pp 582-590.

Franca, A. S., Oliveira, Mendonça, J.C.F., \& Silva (2004) Physical and chemical attributes of defective crude and roasted coffee beans, Food Chemistry 90 (2004) (1-2), pp. 84-89.

Gosh, B. N. 1969. Physical properties of the different grades of arabica beans. Transactions of the ASAE, 9(3):592-593.

Helmy, M. A. 1995. Determination of static friction coefficient of some Egyptian agricultural products on various surfaces. Misr J. of Agr. Eng., 12(1):267-282.

Irvine, D. A., D. S. Jayas, N. D. G. White and M. G. Britton. 1992. Physical properties of flaxseed, lentils, fababeans. Can. Agric. Eng. 34(1):75-82.

Korayem, A. Y. and S. N. Soliman. 1983. Effect of rough rice on its physical properties. Com. Agrisic, Dev. Res. Vol (5).

Kukelko, D. D. S. Jayas, N. D. G. White and M. G. Britton. 1988. Physical properties of Canola (Rapeseed) meal. Can. Agric. Eng. 30(1):61-64.

Ky, C. L., J. Louarn, S. Dussert, B. Guyot, S. Hamon and M. Noirot, (2001) Caffeine, trigonelline, chlorogenic acids and sucrose diversity in wild coffea arabica L. and coffea canephora P. accessions, Food Chemistry 75 (2001), pp. 223-230.

Lingle T.R. (1993) The basics of cupping coffee, Specialty Coffee Association of America, Long Beach (1993). 
Macrae (1985). Nitrogenous compounds. In: R.J. Clarke, \& R. Macrae (Eds.), Coffee, Vol 1: Chemistry (pp. 115-152). London: Elsevier Applied Science.

Martín, Pablos, \& González (1998) Discrimination between arabica and robusta green coffee varieties according to their chemical composition, Talanta 46 (1998), pp. 1259-1264.

Mohsenin, N. N. 1970. Physical properties of plant and animal materials. New York, Gordon and Breach, Sc. Pub. Pp, 51-87, 889.

Muir, W. E. and R. N. Sinha. 1988. Physical properties of cereal and oilseed cultivars grown in western Canada. Can. Agric. Eng. 30(1):51-55.

Odunfa, S. A. 1985. African fermented foods. In : Microbiology of fermented foods (Wood, B. J. ed.) vol. 2, pp. 155-191, Elsevier, Amsterdam.

Oje, K. and E. C. Ugbor. 1991. Some physical properties of oil bean seed. J. Agric. Eng. Res. 50, 305-313.

Rodrigues, M. A. A., Borges, M. L. A., Franca, A. S., Oliveira, L. S. \& Correa, P. C. (2003). Evaluation of physical properties of coffee during roasting. Agricultural Engineering International: The CIGR Journal Of Scientific Research And Development, 5, Manuscript FP 03004, 12pp.

Sivetz, \& Desrosier (1979) M. Sivetz and N.W. Desrosier, Coffee technology, Avi Publishing Co, Westport, Co (1979).

Stennert A. and H.G. Maier, (1996). Trigonelline in coffee. III. Calculation of the degree of roast by trigonelline/nicotinic acid ratio. New gas chromatographic method for nicotinic acid, Zeitschrift für Lebensmitteluntersuchung und -Forschung A 202 (1996), pp. 45-47.

Sylvian, P. G. 1956. Le Café du Yemen. L'Agronomie Tropicale XI(1):62-73. 


\section{الملخص العربى \\ تصميم وتصنيع نموذج لالة تقشير البن اليمنى \\ دكتور /عبدالاله عمر أحمد سيف}

ان دراسة الخصائص الهندسية للمنتجات الزر اعية له اهمية قصوى الهيل في عمليات الاعداد و التداول

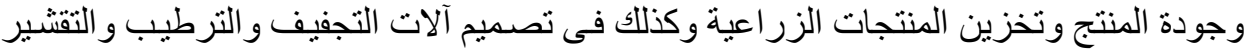

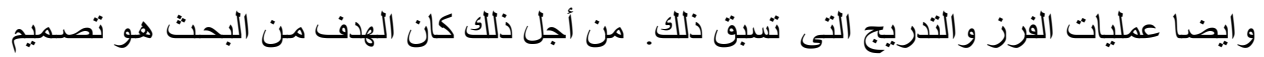

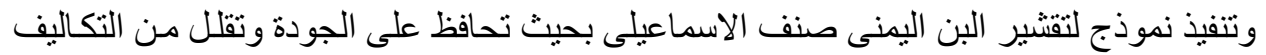
و استهلاك الطاقة. وتتركب الالة من خزان ، ودرفيل وموتور وبكر وسيور و واطار يحمل الالية.

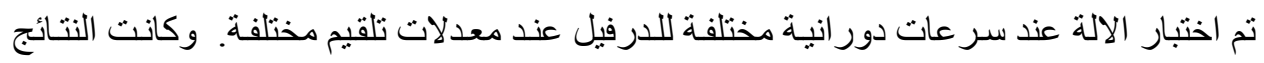

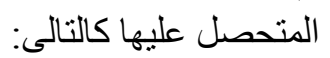

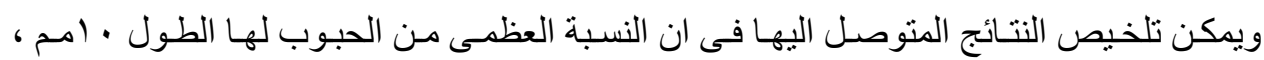



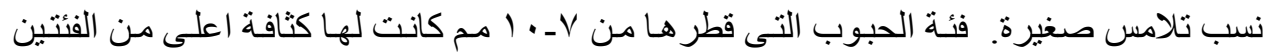

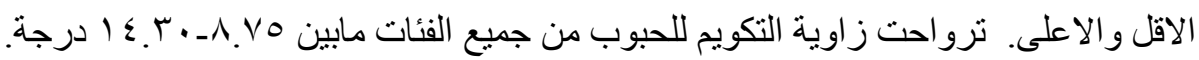
الانتاجية للالة تز ايدت مع زيادة سر عة دور ان الدرفيل عند معدلات التلقيم المختلفة.

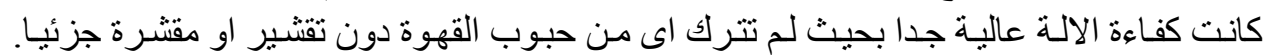

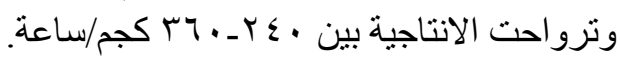

*أستاذ بقسم الهندسة الزراعية ـ كلية الزراعة جامعة صنعاء - ج. ى. 